\title{
PENTAS WAYANG BOCAH SEBAGAI SARANA MEDIA PENDIDIKAN SENI UNTUK ANAK USIA DINI
}

\author{
Oleh: \\ Joko pamungkas \\ PAUD FIP Universitas Negeri Yogyakarta \\ Joko anoman@yahoo.com
}

\begin{abstract}
Abstrak
Pertunjukan seni wayang bocah memiliki beberapa fungsi, salah satunya sebagai sarana media pendidikan. Kegiatan seni pentas wayang bocah dapat dijadikan media mendidik anak untuk bersikap dewasa dan menghindari tingkah laku yang menyimpang. Nilai-nilai keindahan dan keluhuran pada wayang bocah dapat mengasah perasaan seseorang. Secara umum konsep wayang bocah sebagai sarana pendidikan seni berfungsi untuk membantu pertumbuhan dan perkembangan anak, Membina perkembangan estetika, dan Membantu menyempurnakan kehidupan.
\end{abstract}

Kata kunci: Wayang,bocah.aud

\begin{abstract}
Performing arts puppet boy has several functions, one of them as a means of educational media. Boy puppet arts activities can be used as a medium of education such as educating children to be mature and avoid deviant behavior. The values of beauty and greatness of the puppet boy can sharpen one's feelings. In general, the concept of child puppet as a means of education serves to help the growth and development of children, Fostering the development of aesthetics, and helps enhance life.
\end{abstract}

Keywords: Puppet, bocah.aud

PENDAHULUAN

Hakikat paling dalam yang hendak dicapai melalui pendidikan adalah perkembangan maksimal dari jasmani dan rohani anak. Untuk mencapainya tujuan pendidikan tersebut terutama pendidikan di lingkungan anak usia dini salah satu alat media yang dapat dimanfaatkan adalah seni wayang bocah. Seni wayang bocah hadir dalam kurikulum Prodi PG PAUD UNY yang tersirat dalam mata kuliah estetika koreografi anak usia dini sebagai bidang studi yang menyajikan kesempatan pada siswa anak usia dini untuk memperoleh pengalaman-pengalaman berkesenian terutama seni tari. Pengalaman ini kemudian didayagunakan untuk menunjang usaha pendidikan. Pengalaman tersebut dimaksudkan sebagai suatu kegiatan yang ada dalam lingkup kesadaran artistik, yaitu kesadaran seperti ketika seseorang berkarya, kesadaran menghayati seperti halnya apresiator seni yang dihadapi. Jadi apa yang dilaksanakan oleh siswa anak usia dini sama wataknya dengan kegiatan seni yang nyata-nyata sebagai kegiatan yang dapat menjadi wadah penuangan ekspresi dan kreatifitas. Ada berbagai macam cara yang dapat ditempuh dalam usaha untuk menumbuhkan imajinasi kreatif anak usia dini . kegiatan ini tak ubahnya dengan latihan-latihan lain yang sejenis. Pada latihan ini, senantiasa kita harus membantu anak-anak dalam mengungkapkan kembali secara estetik tentang apa yang pernah ia lihat, kerjakan dan tentang apa yang ia mampu banyangkan. Pertunjukan pentas seni wayang bocah memiliki beberapa fungsi, salah satunya sebagai sarana media pendidikan. Kegiatan berkesenian terutama seni tari yang di bingkai dalam wayang bocah dapat dijadikan media pendidikan seperti mendidik anak untuk bersikap dewasa dan menghindari tingkah laku yang menyimpang. Nilai-nilai 
keindahan dan keluhuran pada tokoh dan cerita wayang dapat mengasah perasaan anak tersebut.

\section{Rumusan Masalah}

1. Apa makna pertunjukan wayang bocah bagi anak usia dini?

2. Apa makna media pendidikan seni melalui wayang bocah bagi anak usia mdini?

3. Apa fungsi pertunjukan wayang bocah sebagai sarana media pendidikan seni bagi anak usia dini?

\section{PEMBAHASAN \\ Makna Pertunjukan wayang bocah Makna Pertunjukan}

Pertunjukan adalah karya seni yang melibatkan aksi individu atau kelompok ditempat dan waktu tertentu. Id. Wikipedia. org/ wiki/ seni_pertunjukan . Performance biasanya melibatkan empat unsur yaitu waktu, ruang, tubuh pelaku, dan hubungan pelaku dengan penonton.

\section{Makna Tari dalam wayang bocah untuk anak usia dini}

Tari adalah gerakan-gerakan yang diberi bentuk dan ritme dari badan di dalam ruangan. Definisi tari tersebut lebih dikemukakan oleh Hartong dari Belanda dalam bukunya yang berjudul Dunskunst (Sudarsono tanpa tahun). Jika kita cermati pengertian tari yang dikemukakan oleh Hartong tersebut, menjelaskan bahwa tari sebagai bentuk seni selalu mengggunakan media badan/tubuh manuasia untuk mengungkapkan ekspresinya dalam bentuk gerak yang ritmis yang dapat dilakukan di dalam ruang. (Dra. Ninik Harini. 2002). Pengertian ruang disini adalah tempat yang dapat digunakan untuk melakukan gerakgerak tari, miasalnyaa di ruang kelas, di dalam studio, di halaman sekolah, di panggung atau tempat lain yang memungkinkan untuk bergerak. Unsur utama tari adalah gerak. Gerak tari selalu melibatkan unsur anggota badan atau tubuh manusia. (Rosjid Abdurachman, BA dan Iyus Rusliana, BA. 1979). Unsur- unsur anggoata badan atau tubuh tersebut di dalam membentuk gerak tari, dapat berdiri, bergabung ataupun bersambungan.

\section{Makna Media Pendidikan seni untuk anak usia dini \\ Media merupakan alat bantu dalam proses belajar mengajar. Guru di} lingkungan anak usia dinipun sadar bahwa tanpa bantuan media, maka bahan dan materi pelajaran sukar untuk dicermati dan dipahami oleh setiap anak usia dini. Sebagai alat bantu, media mempunyai fungsi melicinkan jalan menuju pengalaman. (Drs. Syaiful Bahri Djamarah dan Drs. Aswan Zain. 2006). Hal ini dilandasi dengan keyakinan bahwa proses belajar mengajar dengan bantuan media mempertinggi kegiatan belajar anak didik dalam tenggang waktu yang cukup lama. Itu berarti kegiatan belajar mengajar anak didik dengan bantuan media akan menghasilkan proses dan hasil belajar yang lebih baik daripada tanpa bantuan media. Pertunjukan wayang bocah sebagai sarana media pendidikan juga merupakan sebagai alat bantu untuk memperkaya wawasan anak didik. Maka dapat dipahami bahwa media adalah alat bantu dalam proses belajar mengajar. Dan gurulah yang mempergunakannya untuk membelajarkan anak didik demi tercapainya tujuan pembelajaran.

Fungsi Pertunjukan wayang bocah Sebagai Sarana Media Pendidikan seni bagi anak usia dini

Materi Pembelajaran tari yang bterbungkus dalam seni wayang bocah bagi anak usia dini bersifat membantu pendewasaan anak. Pendayagunaan seni wayang bocah mempunyai fungsi yang bersifat edukatif. Dengan demikian konsep seni wayang bocah dalam bingkai seni gerak dan sosiodarama sebagai sarana atau media pendidikan adalah konsep pendidikan seni yang paling sesuai bagi anak-anak usia dini. Secara umum konsep seni yang terbingkai dalam seni wayang bocah sebagai sarana pendidikan yang 
berfungsi untuk membantu pertumbuhan dan perkembangan anak, Membina perkembangan estetika, dan Membantu menyempurnakan kehidupan.

Fungsi-fungsi tersebut di atas tidak dimaksudkan membentuk anak usia dini untuk dicetak menjadi penari atau seniman tari, tetapi semata-mata untuk pengembangan mental, fisik dan perasaan estetik.

Diatas telah diungkap bahwa seni wayang bocah yang terbingkai dalam seni tari mempunyai fungsi membantu pertumbuhan dan perkembangan anak, memberi perkembangan estetik, dan membantu penyempurnaan kehidupan. Oleh karena itu, seni wayang bocah tidak berupa latihan-latihan untuk menjadikan anak usia dini menjadi penari wayang, penari topeng, atau penari-penari tokoh tokoh lain, walaupun ada di antara anak usia dini yang memiliki bakat untuk menjadi penari yang baik, tetapi itu bukan merupakan tujuan yang utama. Bakat itu dapat dibina tersendiri. Agar calon guru memahami bagaimana pembinaan berkesenian khususnya seni tari pada lembaga anak usia dini, maka perlu dikaji terlebih dahulu fungsi pertunjukan seni wayang bocah sebagai sarana media pendidikan.

\section{Fungsi wayang bocah untuk membantu pertumbuhan dan perkembangan anak.}

Pertumbuhan adalah proses berkelanjutan yang meliputi perkembangan dari semua kecakapan dan potensi anakusia dini. Pengalaman pentas seni wayang bocah memberikan kesempatan bagi kelangsungan proses tersebut. Peranan seni wayang bocah dalam membantu pertumbuhan dan perkembangan anak dapat dilihat antara lain untuk meningkatkan pertumbuhan fisik, mental dan estetika, memberi sumbangan ke arah sadar diri, membina imajinasi kreatif dan memberi sumbangan ke arah pemecahan masalah. a. Pentas seni wayang bocah meningkatkan pertumbuhan fisik, mental dan estetik

Jenis pengalaman seni untuk meningkatkan pertumbuhan fisik ditunjukan dengan perkembangan motorik anak usia dini dalam gerak-gerak bebas dalam menari. Kegiatan semacam ini memberikan kesempatan fisik untuk tumbuh sempurna dan secara langsung mental juga berkembang. Karena kegiatankegiatan dalam melakukan gerak-gerak tari juga melibatkan kesadaran estetik, maka pertumbuhan estetik juga mendapat kesempatan untuk tumbuh.

b. Pentas seni wayang bocah memberikan sumbangan ke arah sadar diri

Melalui kegiatan wayang bocah keunikan anak-anak akan terbina. Karenanya anak dapat mengenali dirinya sendiri dengan baik. Dengan demikian diri anak dapat berkembang dan ini menyebabkan tumbuhnya inisiatif, kemampuan mengkritik, kepemimpinan dan kreasi. Anak merasakan keberadaannya memiliki arti. Terutama jika dia diberi peran tertentu dalam suatu kegiatan artistik/ estetik, misal dalam diskusi kecil antar teman tentang sebuah gerak tokoh tokoh wayang, gerak berpasangan, mereka akan aktif dan saling memberikan sumbangan pikiran. Anak juga merasakan akibat-akibat dari perbuatanya sehingga inisiatif untuk mencari bentuk-bentuk lain yang dirasakan lebih baik, akan selalu dilakukan. Proses ini menjadi dasar untuk kemampuan mengkritik dan memimpin. Jika awalnya anak-anak egois ke"aku"annya masih besar, menghilang, berubah menjadi rasa sosial.

c. Pentas seni wayang bocah membina imajinasi kreatif

Imajinasi kreatif itu sangat vital bagi anak. Oleh karena itu, setiap usaha pendidikan kearah menumbuh kembangkan imajinasi kreatif merupakan usaha yang sangat baik. Dalam hubungan ini seni tari menjadi penting, karena wayang bocah selalu memberikan 
kesempatan berimajinasi kreatif. Contohnya seorang anak paud akan selalu berkhayal bahwa dia akan menjadi tokoh yang kuat seperti tokoh bima, anoman, kumbakarno disegani sehingga dalam imajinasinya dia dapat mengalahkan musuh-musuhnya dengan mudah. Gerakgerak dan mimik yang dilakukan sangat menggambarkan kuatnya suatu imajinasi tertentu. Jika diberi kesempatan menirukan raja, dia akan benar-benar berkhayal seandainya aku menjadi raja . Kegiatankegiatan bermain dalam aneka gerak akan membina imajinasi mereka, sehingga secara langsung akan berkembang.

d. Pentas seni Wayang bocah memberi sumbangan ke arah pemecahan masalah

Pemecahan masalah merupakan hal yang penting dalam pendidikan maupun dalam kehidupan sehari-hari. Seni Wayang bocah memberi sumbangan terhadap perkembangan pemecahan masalah. Dalam aktifitas pentas seni wayang bocah anak usia dini dapat memunculkan gagasan-gagasannya yang menjadi benarbenar konkret. Motivasi guru memang sangat diperlukan agar anak selalu dapat menyelesaikan persoalan sendiri. Jika belum dapat, dianjurkan agar diselesaikan antara teman sampai mempunyai keputusan-keputusan tertentu. Manusia akan selalu menghadapi masalah, sehingga melalui kegiatan wayang boacah, siswa paud juga terlatih untuk memecahkan masalah.

e. Pentas seni wayang bocah memurnikan cara berfikir, berbuat dan menilai

Melalui kegiatan seni wayang bocah, kehidupan siswa Paud dapat diperkaya dengan proses penjelajahan tersebut, dibutuhkan penyusunan pengalaman secara kreatif dan sensitif. Jika siswa PAUD bermain, aktivitas mereka juga melibatkan pikiran. Jika siswa PAUD bermain, aktivitas mereka juga melibatkan pikiran. Jika mereka menirukan gerak alam atau binatang, mereka juga berpikir bahwa gerak-gerak yang dilakukan seperti apa yang mereka amati. Aktivitas ini akan memberikan pertanyaan "apakah gerakanku" baik. Keputusan yang diberikan tersebut akan menjadi proses menilai yang bijaksana, sehingga dapat dipastikan mereka akan melakukan pengubahan-pengubahan untuk sesuatu yang lebih baik.

f. Pentas seni wayang bocah memberikan sumbangan kepada perkembangan kepribadian

Dewasa ini penilaian terhadap keberhasilan pendidikan dilihat pada ada atau tidak adanya perkembangan kepribadian karena kepribadian dipandang penting dalam suatu kehidupan. Ekpresi bebas dalam masyarakat yang merupakan penyesuaian emosional itu pada akhirnya mematangkan kepribadian. Usaha-usaha mematangkan kepribadian dalam pentas seni wayang bocah dapat dilakukan guru dengan cara membantu penyesuaian rasa emosionalnya, membantu menghilangkan perasaan terikat, membantu menghilangkan perasaan takut, membantu menekan kekecewaan, memberikan kepercayaan serta mendorong anak agar selalu berbuat positif. Hal-hal tersebut dapat dilakukan lewat semua kegiatan pembelajaran seni tari.

\section{Seni wayang bocah membina perkembangan estetika}

Perkembangan estetika diperlukan bagi pendewasaan secara utuh terhadap pribadi anak musia dini. Perkembangan estetik ini dapat dibina melalui kegiatan wayang bocah yang berupa penghayatan, apersepsi, ekspresi dan kreasi.

Melalui wayang bocah pancaindra anak akan terlatih, penghayatan menjadi kuat dan keputusan visual akan berkembang menjadipeka kritis. Melihat bukan merupakan fungsi mata semata, tetapi melibatkan seluruh indra ditambah dengan visi batin. Demikian pula ketika mendengar, bersuara, ataupun bergerak. Cara melatih pancaindra dan seluruh anggota tubuh harus melalui proses kegiatan tanpa paksaan, dengan memperhitungkan tiga faktor berikut 
Harus mengembangkan konsep-konsep baru, Harus menciptakan situasi yang dapat memberikan dorongan untuk memacu kegiatan dengan penuh ketelitin, dan Harus menjadi kesempatan belajar menilai terhadap apa yang dilakukan.

Pentas seni Wayang bocah adalah proses mewujudkan perasaan dengan melibatkan kesadaran estetik dan keputusan kritis. Orang yang telah berkembang perasaan estetiknya akan sanggup mengapresiasi kualitas seni dan pengalaman sehari-hari.

Pentas seni Wayang bocah memberikan dorongan terhadap kelangsungan ekspresi anak-anak karena setiap kegiatan seni selalu menyajikan kesempatan bagi anak didik untuk mempertahankan kebebasan berekspresi.

Daya kreatif tetap terpendam di dalam diri tiap anak kalau tidak ditolong pemunculannya. Daya kreatif berbeda dengan bakat dalam seni. Seni disajikan bagi semua anak. Baik yang mempunyai bakat maupun tidak. Tujuan wayang bocah di PAUD bukan untuk mengembangkan bakat seni melainkan untuk mengembangkan seluruh potensi yang diliki anak.

\section{Pentas seni wayang bocah membantu menyempurnakan kehidupan}

Unsur kehidupan yang mendorong ekspresi akan mendatangkan pengetahuan bagi anak didik. Sebaliknya, keinginan anak untuk mengetahui kehidupan, mengimajinasikan kehidupan, akan menyempurnakan kehidupan anak. Oleh karena itulah wayang bocah dapat memberikan bantuan menyempurnakan kehidupan anak didik yang antara lain ditunjukkan dengan kehidupan yang kteatif dan kehidupan sosial baik. Karena pada dasarnya wayang bocah dapat memberikan kebebasan berimajinasi dan berkreasi, maka secara langsung seni wayang bocah menjadi suatu yang menarik perhatian anak usia dini. Kondisi ini sangat menguntungkan bila digunakan untuk mendorong minat kegiatan-kegiatan eksplorasi

menarik perhatian anak usia dini. Kondisi ini sangat menguntungkan bila digunakan untuk mendorong minat kegiatan-kegiatan eksplorasi maupun eksperimentasi gerak. Pada saatnya kondisi ini akan menjadikan pengalaman anak semakin lengkap.

Kegiatan wayang bocah yang mengembangkan pengalaman individual dan sosial akan menjadikan anak-anak lebih sadar terhadap efisiensi secara ekonomis dalam masyarakat. Sesab secara individuual anak belajar mengenal perbedaan antara ketrampilan yang baik dan yang jelas, menemukan benda-benda yang berwajah menarik dan tidak menarik. Secara sosial, anak dapat mengembangkan pilihan dan pendapatnya kepada masyarakat.

Bagi anak-anak yang berbakat, kegiatan seni memberikan kesempatan untuk berlatih dalam seni tari. Disamping kegiatan-kegiatan yang ditentukan oleh jadwal sekolah, anak-anak mendapatkan kesempatan menggunakan waktu senggangnya terbuka horizon baru bagi hobi, bagi pekerjaan sampingan dan pekerjaan kejujuran untuk sumber nafkah dikemudian hari nanti.

\section{KESIMPULAN}

Pertunjukan seni wayang bocah memiliki beberapa fungsi, salah satunya sebagai sarana media pendidikan. Kegiatan wayang bocah dapat dijadikan media pendidikan seperti mendidik anak untuk bersikap dewasa dan menghindari tingkah laku yang menyimpang. Nilai-nilai keindahan dan keluhuran pada wayang bocah dapat mengasah perasaan seseorang.

Wayang bocah yang didalamnya mengandung gerakan dan dialaog adalah gerakan-gerakan yang diberi bentuk dan ritme dari badan di dalam ruangan. Definisi tari tersebut lebih dikemukakan oleh Hartong dari Belanda dalam bukunya yang berjudul Dunskunst (Sudarsono tanpa 
tahun). Jika kita cermati pengertian tari yang dikemukakan oleh Hartong tersebut, menjelaskan bahwa tari sebagai bentuk seni selalu mengggunakan media badan/tubuh manuasia untuk mengungkapkan ekspresinya dalam bentuk gerak yang ritmis yang dapat dilakukan di dalam ruang.

$$
\text { Pertunjukan wayang bocah }
$$
sebagai sarana media pendidikan juga merupakan sebagai alat bantu untuk memperkaya wawasan anak didik. Maka dapat dipahami bahwa media adalah alat bantu dalam proses belajar mengajar. Dan gurulah yang mempergunakannya untuk membelajarkan anak didik demi tercapainya tujuan pembelajaran.

Wayang bocah bersifat membantu pendewasaan anak. Pendayagunaan wayang bocah mempunyai fungsi yang bersifat edukatif. Dengan demikian konsep seni tari sebagai sarana atau media pendidikan adalah konsep pendidkan yang paling sesuai bagi anak usia dini. Secara umum konsep wayang bocah sebagai sarana pendidikan berfungsi untuk membantu pertumbuhan dan perkembangan anak, Membina perkembangan estetika, dan Membantu menyempurnakan kehidupan. Agar calon guru memahami bagaimana pembinaan seni di anak usia dini, maka perlu dikaji terlebih dahulu fungsi pertunjukan tari sebagai sarana media pendidikan. 1. fungsi seni wayang bocah untuk membantu pertumbuhan dan perkembangan anak. Seni Wayang bocah dalam membantu pertumbuhan dan perkembangan anak dapat dilihat antara lain untuk meningkatkan pertumbuhan fisik, mental dan estetika, memberi sumbangan ke arah sadar diri, membina imajinasi kreatif dan memberi sumbangan ke arah pemecahan masalah, wayangt bocah memurnikan cara berfikir, berbuat dan menilai, wayang bocah memberikan sumbangan kepada perkembangan kepribadian.2 Fungsi seni wayang bocah membina perkembangan estetika. Perkembangan estetika diperlukan bagi pendewasaan secara utuh terhadap pribadi anak usia dini. Perkembangan estetik ini dapat dibina melalui kegiatan seni wayang bocah yang berupa penghayatan, apersepsi, ekspresi dan kreasi. 3 fungsi seni wayang bocah membantu menyempurnakan kehidupan. Unsur kehidupan yang mendorong ekspresi akan mendatangkan pengetahuan bagi anak didik. Sebaliknya, keinginan anak untuk mengetahui kehidupan, mengimajinasikan kehidupan, akan menyempurnakan kehidupan anak. Oleh karena itulah seni wayang bocah dapat memberikan bantuan menyempurnakan kehidupan anak didik yang antara lain ditunjukkan dengan kehidupan yang kreatif dan kehidupan sosial baik.

\section{DAFTAR PUSTAKA}

Rosjid Abdurachman, BA dan Iyus Rusliana, BA. 1979. Seni Tari III. Jakarta: C.V. Angkasa.

Syaiful Bahri Djamarah dan Aswan Zain. 2006. Srategi Belajar Mengajar. Jakarta: Rineka Cipta.

Purwaningsih dan Ninik Harini. 2002. Pendidikan Seni Tari-Drama SD. Malang : Universitas Negeri Malang (UM Press).

Id. Wikipedia. org/ wiki/ seni_pertunjukan 